\title{
Concept of standard raw drug substitution in Traditional Siddha Medicine - A Review
}

\author{
Review Article
}

\section{Shyamala Rajkumar'1, Vinayak S², Eugene Wilson ${ }^{3}$, Shree Devi M S4*, Vijayakumar V5, Sunil Kumar K N6, Aravind D7, Sivakumar L', Kanakavalli K 9}

\author{
1. Research Officer - Sci - III, Central Council for Research in Siddha, Chennai, Tamil Nadu, India. \\ 2. Research Officer, Siddha Central Research Institute (Central Council for Research in Siddha), Chennai, Tamil Nadu, India. \\ 3. Research Officer, Central Council for Research in Siddha, Chennai, Tamil Nadu, India. \\ 4. Research Officer, Siddha Central Research Institute (Central Council for Research in Siddha), Chennai, Tamil Nadu, India. \\ 5. Scientific Officer - Siddha, PCIM\&H, PLIM Building, 2nd Floor, Kamala Nehru Nagar, Ghaziabad, India. \\ 6. Research Officer, Siddha Central Research Institute (Central Council for Research in Siddha), Chennai, Tamil Nadu, India. \\ 7. Assistant Professor, National Institute of Siddha, Chennai, Tamil Nadu, India. \\ 8. Chief Executive, Dr Siva Ayush Pharma Services, Arumbakkam, Chennai, India. \\ 9. Central Council for Research in Siddha, Chennai, Tamil Nadu, India.
}

\begin{abstract}
Classical Siddha medicine recommends the usage of functionally parallel substitute raw drugs in the scarcity of the original material. The concept of standard raw drug substitution is designated by the Tamil term Matru sarakku, which emphasizes selecting alternatives either in herbal or non-herbal sources based on certain attributes. Functionally similar materials are suggested for balancing the deficit based on such parameters. Literature sources from Siddha medicine and other allied subjects were explored and documented for the inclusive understanding of the concept of ideal substitution. Few of the standard substitutes mentioned in the classical Siddha literature were evaluated in a scientific account for its justification. An outlook on different specimens as described in the ancient texts of Tamil medicine indicates the usage of substitutes from numerous plants, animals, and other metallo-mineral ingredients. The rationale of selecting alternatives primarily depends on the equivalent following traditional attributes like organoleptic entities, potency, division, general properties, specific actions, and medicinal uses of the material shared between the raw drugs. This must undergo a systematic evaluation by pharmacognostic and phytochemical studies to justify current practices of substitution. A systematic document in these lines will give a proper guideline for the effective employment of substitute drugs in the current scenario of dwindling official botanical sources for many Traditional Siddha formulations.
\end{abstract}

Key Words: Agathiyar Vaidhya Chinthamani, Raw drug Substitutes, Siddha literature, Traditional Siddha Medicine, Traditional attributes.

\section{Introduction}

The global renaissance in indigenous medicines and therapies has escalated the herbal commodity market. (1) The effectiveness of traditional medicine is contingent upon the proper use of sustained availability of genuine raw materials. Approximately $80 \%$ of the population from developing nations depend on herbal raw drugs or their products for their primary health care needs. Many of the prescribed medicines or consumer health care products intended for wellness that is marketed worldwide are derivatives from plant species chiefly of wild origin. (2) According to Hamilton, the

\section{* Corresponding Author:}

Shree Devi M S

Research Officer, HOD, Department of Pharmacy, Siddha Central Research Institute (Central Council for Research in Siddha), Arumbakkam,

Chennai, Tamil Nadu, India

Email Id: shreemd@gmail.com
Indian subcontinent is a rich source of flora in which nearly $44 \%$ of it is used for medicinal purposes. (2) AYUSH system of medicines as a whole uses nearly 2400 herbal species, apart from around 6000 species used in other Indian folklore traditions. $(3,4)$ A total of 9600 registered pharma industries, other unregistered firms, recognized practitioners and native healers all depend on the present limited resources to meet the needs of the public health sector. (3) Only less than 10\% of the cultivated source is available in the market and fact, most of the ingredients either fresh or dry are procured directly from its natural habitat. This resulted in massive depletion of resources. The soaring demand versus inadequacy is a long pending issue confronted by the current herbal trade; the scarcity brings about irrational use of adulterants and substitutes in place of authentic materials.

As one of the popular medical systems of south Indian peninsular regions, Siddha medicine uses a substantial part of raw drugs from the herbal vegetation. (9) Herbal products are the key entity to any sort of remedial measures affirmed by the practitioners of 
Shyamala Rajkumar et.al., Concept of standard raw drug substitution in Traditional Siddha Medicine - A Review

Traditional Siddha Medicine (TSM). The vast materia medica embraces descriptions of thousands of medicinal plants and their by-products to be used in its exquisite formulary arsenal. $(10,11)$

The notion of using genuine replacements to the unobtainable herbal resources are documented in the classical Siddha texts. The treatise about raw drug substitution by sage Agathiyar, in his Tamil medical text Agathiyar Vaidhya Chinthamani (AVC) throws light on the numerous prospects of using tributary herbal and non-herbal resources in the absence of original materials. (12) The terminology 'Matru sarakku' (MS) in Siddha medicine is defined as the usage of reliable alternatives in the absence or inaccessibility of the raw drug in demand. $(12,13)$

As numerous substitutes mentioned in the classical books, an attempt was made to document a few of the established substitute pairs and their rational part in the light of scientific understandings done in this review paper.

\section{Methodology}

Literature sources from Siddha medicine and other allied subjects were explored and documented for an inclusive understanding of the concept of MS. The detailed list of substitutes used in current practices is interpreted from the published journals, books, and periodicals. Few of the standard substitutes mentioned in the classical Siddha works were evaluated from a scientific viewpoint for their justified usage.

\section{Observation and Discussion}

Unethical substitution and adulteration are the major trends in the market. The deceitful practice that has been done intentionally for commercial gain comes under unethical substitution. In the south Indian market alone, there is 70 to $100 \%$ reported adulteration in raw drugs like Nuna (Morinda tinctoria Roxb.), Maramanjal (Coscinium fenestratum (Goetgh.) Colebr) and Vaividangam (Embelia ribes Burm.f.).(3) The fraudulent practice of unethical substitution and adulteration causes serious health complications starting from liver and kidney failure or even up to multiple organ failure. (14) There are so many motives that result in substantial adulteration that occur primarily due to scarcity of raw drug resources or depletion of the source, cost of the drug or overheads in procuring, resemblance in morphological and organoleptic characters between substitute and original drugs, seasonal unavailability, geographical or regional substitution etc. $(3,14)$ List of common substitutes/ adulterants and standard substitutes available in the raw drug market is tabulated (Table 1). From the list, it can be inferred that the practice of adulteration is more common than the approved substitutes. (15-31)

Table 1- List of raw drugs which are employed as substitutes in the market

\begin{tabular}{|c|c|c|c|c|}
\hline S.No & $\begin{array}{l}\text { Tamil Name of } \\
\text { original Raw drug }\end{array}$ & Botanical name & Part used & Substituted with \\
\hline 1 & Akayathamarai & Pistia stratiotes Linn. & Whole plant & $\begin{array}{l}\text { Whole plant of Eichhornia crassipes } \\
\text { (Mart.) Solms }\end{array}$ \\
\hline 2 & Asoku & Saraca asoca (Roxb.) de Wilde. & Bark & Bark of Shorea robusta Gaertn.f. \\
\hline 3 & Athimathuram & Glycyrrhiza glabra Linn. & Root & Root of Abrus precatorius Linn. \\
\hline 4 & Chiruthekku & Clerodendron serratum Linn. & Bark & The bark of Premna herbacea Roxb. \\
\hline 5 & $E t t i$ & Strychnos nux vomica Linn. & Seed & Seeds of Strychnos potatorumWilld. \\
\hline 6 & Iruvi & Dryopteris filix-mass Linn. & Fern (Rhizome) & Rhizome of Osmunda claytoniana Linn. \\
\hline 7 & Pushkaramoolam & Inula racemosa Hook.f. & Root & Root of Saussurea costus (Falc.) Lipsch. ${ }^{*}$ \\
\hline 8 & Kontrai & Cassia fistula Linn. & Bark & The bark of Acacia leucophloea Willd. \\
\hline 9 & Kookaineeru & Maranta arundinacea Linn. & Rhizome starch & Rhizome starch of Tacca pinnatifeda Forst. \\
\hline 10 & Kudasapalai & Holarrhena antidysenterica Linn. & Bark & The bark of Wrightia tinctoria $\mathrm{R} . \mathrm{Br}$. \\
\hline 11 & Manjitti & Rubia tinctorium Linn. & Root & The root of Rubia cordifolia L. * \\
\hline 12 & Mookirattai & Boerhavia diffusa Linn. & Whole plant & $\begin{array}{c}\text { Whole plant of Trianthema portulacastrum } \\
\text { Linn. }\end{array}$ \\
\hline 13 & $N a b i$ & Aconitum napellus Linn. & Root & $\begin{array}{c}\text { The root of Aconitum chasmanthum Stapf ex } \\
\text { Holmes }\end{array}$ \\
\hline 14 & Nervalam & Croton tiglium Linn. & Seeds & Seeds of Baliospermum montanumWilld. \\
\hline 15 & Nilavagai & Cassia senna Linn. & $\begin{array}{l}\text { Leaves and } \\
\text { pods }\end{array}$ & Leaves and pods of Pluchea lanceolata \\
\hline 16 & Peetharohini & Coptis teeta Wall. & Root & The root of Thalictrum foliosum DC. \\
\hline 17 & Poonaikkali & Mucuna pruriens Linn. & Seed & Seeds of Mucuna utilis Wall. \\
\hline 18 & Sathappu/Aruvatha & Ruta graveolens Linn. & $\begin{array}{l}\text { Leaves } \\
\text { Whole plant }\end{array}$ & Whole plant of Ruta chalepensis Linn. * \\
\hline 19 & Sirunagapoo & Mesua ferrea Linn. & Flower buds & Flower buds of Cinnamomum wightii* \\
\hline 20 & Sitramutti & Sida rhombifolia Linn. & Root & Root of Pavonia odorata Willd. \\
\hline 21 & Vaividangam & Embelia ribes Linn. & Fruit & Fruit of Embelia tsjeriamcottam DC* \\
\hline 22 & Vettiver & Vetiveria zizanioides Linn. & Root & Root of Coleus vettiveroides Jacob * \\
\hline
\end{tabular}

* Substitute widely used in the market 
Unavailability of raw drugs due to the mass extinction of genuine species is the major concern of AYUSH pharma industries. As per the 2015 IUCN, red list of threatened plants in India, a total of 18 plant species have become extinct, 41 under extinct/ endangered category, 52 plant species under endangered class, 102 under vulnerable status, and 251 under rare status. The updated list of IUCN (2015) includes 44 Indian plants. This includes many of the widely used medicinal plants in the AYUSH system of medicines. $(2,32)$ Some of the commonly used Siddha herbs like Athividayam (Aconitum heterophyllum Wall. ex Royle) and Sadamanjil (Nardostachys jatamansi (D.Don) DC.) are already on the critically endangered list. (14)

Many unethical substitutions and adulteration practices are based on the morphological similarity of raw drugs with that of the original drugs observed. The dried juice of Knema angustifolia Roxb resembles that of Pterocarpus marsupium. Roxb and hence it is substituted. The style and florets of Kumkumapoo (Crocus sativus Linn.) are adulterated with the dried ray florets of french marigold (Tagetes patula Linn.) because of their striking similarity. $(15,16)$

The similarity in organoleptic characters like taste and odour is another vast area of substitution. E.g. the camphor extracted from leaves of camphor basil (Karpoora Tulasi-Ocimum kilimandscharium Guerke) and Ocimum cannum Sims), possess the characteristic odour and taste of natural karpooram (camphor) obtained from Cinnamomum camphora Linn and therefore substituted. The plant of Mimulus moschatus Dougl has an aroma similar to the original expensive Kasthuri (Musk) and hence adulterated in many places. The essential oil extracted from the leaves of Limnophila rugosa Roth tastes and smells similar to the essential oil from Ocimum basilicum Linn and therefore adulterated. The seeds of Abelmoschus moschatus Medic resemble musk in flavour, therefore used for flavouring oils in place of Kasthuri (Musk). (23)

Illogical substitution is the practice that is unintentionally done due to the lack of awareness or the unfamiliar identity of the prescribed plant species or due to misperception of ingredients in the master formulations. In the majority, most of the substitutes are in practice without the proper authentication or verification of their efficacy or neither aware of the ill effects of substituting it. A single raw drug or herbal material is often used as the substitute for the original material in demand. For eg. Kadukkai pu (The foliar gall of Terminalia chebula Retz.) is misconstrued with completely different Karkadakacinki (The gall of Pistacia intregerrima Stew. Ex Brandis) and used as the substitute. The incongruity of traditional synonyms of several raw drugs is another factor for illogical substitution. For eg. Kanduparanki (Pygmaeopremna herbacea Roxb.) is a synonym of Cirutheku (Clerodendron serratum Linn.), both are entirely different plants but mistaken and used due to the misperception in the vernacular name. $(14,33)$

The logical or standard substitutes (Matru sarakku) are the genuine practice of substitution, mentioned in Siddha medicine, which is justifiable accordingly with the current situation following the norms of traditional practice and established literature. It is justified to use alternatives in the absence of one or more ingredients either for medicinal preparation or for other therapeutic practices. Nevertheless, it is unethical to use the substitute for the prime drug of the formulation. As in Ammukkura Choornam, Ammukkura (Withania somnifera Dunal.), the prime drug should not be replaced with any substitute. ${ }^{34}$ One of the notable recommendations on standard substitutes is from the classical Tamil medical text "Agasthyar Vaidhya Chinthamani".(12) The book details 39 substitute pairs including non-herbal sources. According to various literature works in Siddha medicine, the substitute should have parallel properties in terms of its class (Vargam), source of the essential part (Saram), organoleptic characters like Suvai (taste characteristics) and odour (Manam). In addition, the identical potency (Thanmai) of the substituted raw drug, its general properties (Pothu gunam), special attributes or actions (Ceykai) and therapeutic benefits (Maruthuva gunam) should match with that of the original raw drug. (12) Either of the above criteria has to support with textual references or traditional expert practices for establishing its genuineness. The important substitute pairs are detailed in Table 2.

Table 2- Important Standard raw material substitutes mentioned in the classical text Agasthyar Vaidhya Chinthamani

\section{S.No Original drug}

\begin{tabular}{|l|l|}
\hline 1 & Aadutheenda palai \\
\hline 2 & Arathai \\
\hline 3 & Athimathuram \\
\hline 4 & Athimathuram \\
\hline 5 & Attavarkam $*$ \\
\hline 6 & Chukku \\
\hline 7 & Iluppai \\
\hline
\end{tabular}

\section{$8 \quad$ Kandangathiri}

9 Kandangathiri

10 Karpooram

11
Kavattai

\section{Botanical Name}

Aristolochia bracteolata Lam. Alpinia officinarum Hance. Glycyrrhiza glabra Linn. Glycyrrhiza glabra Linn.

Dry Zingiber officinale Rosc. Madhuca longifolia Koen.

Solanum xanthocarpum Schrad. \&Wendl Solanum xanthocarpum Schrad.\&Wendl Cinnamomum camphora Linn. Siruthekku Cymbopogon nardus (L.) Rendle

\section{Standard substitute}

(Matru sarakku)

Chenthotti

Chukku

Pereechu

Drakshai

Kadukkai

Inji

Sitramutti/ Peramutti

Thalisapathiri

Mulli

Seeragam

\section{Botanical Name}

Pavonia odorata Willd.

Dry Zingiber officinale Rosc.

Phoenix dactylifera Linn.

Vitis vinefera Linn.

Terminalia chebula Retz.

Fresh Zingiber officinale Rosc.

Sida rhombifolia Linn. or

Pavonia odorata Willd.

Abies webbiana Linn.

Solanum anguivi Lam

Clerodendron serratum Linn.

Cuminum cyminum Linn. 
Shyamala Rajkumar et.al., Concept of standard raw drug substitution in Traditional Siddha Medicine - A Review

\begin{tabular}{|c|c|c|c|c|}
\hline 12 & Kodiveli & Plumbago zeylanica Linn. & Etti & Strychnos vomica Linn. \\
\hline 13 & Kudasapalai & $\begin{array}{l}\text { Holarrhena antidysenterica } \\
\text { Linn. }\end{array}$ & Lavangapattai & Cinnamomum verum J.S.Presl \\
\hline 14 & Kumkumapoo & Crocus sativus Linn. & Thamaraikesaram & Stamens of Nelumbo nucifera Gaertn. \\
\hline 15 & MulKiluvai & $\begin{array}{l}\text { Commiphora mukul (Hook. ex } \\
\text { Stocks) Engl. }\end{array}$ & Veppam pisin & Gum of Azadirachta indica A.Juss. \\
\hline 16 & $\mathrm{Nel}$ & Common Oryza sativa Linn. & Chamba nel & Chamba variety of Oryza sativa Linn. \\
\hline 17 & Nervalam & Croton tiglium Linn. & Sivathai & Operculina turpethum Linn. \\
\hline 18 & Pachaipayaru & Vigna radiata (L.) R. Wilczek & Pani payaru & Phaseolus trilobatus (L.) Schreb. \\
\hline 19 & Poolan kizhangu & Phyllanthus reticulatus Poir. & Thamarai kizhangu & Rhizome of Nelumbo nucifera Gaertn. \\
\hline 20 & Purasu & $\begin{array}{l}\text { Butea monosperma (Lam.) } \\
\text { Taub. }\end{array}$ & Peyathi & Ficus hispida L.f. \\
\hline 21 & Saattaranai & Trianthema decandra Linn. & Mookkirattai & Boerhavia diffusa Linn. \\
\hline 22 & Sadamanjil & Nardostacys jatamansi $D C$. & Muthakasu & Cyperus rotundus $L$. \\
\hline 23 & Seeragam & Cuminum cyminum Linn. & Karunseeragam & Nigella sativa Linn. \\
\hline 24 & Sitramutti & Sida rhombifolia Linn. & Peramutti & Pavonia odorata Willd. \\
\hline 25 & Thippili & Piper longum L. & Milagu & Piper nigrum Linn. \\
\hline 26 & Thotti & Pavonia odorata Willd. & Thura & Fumaria officinalis $L$. \\
\hline 27 & Vila & Limonia acidissima Linn. & Vilvam & Aegle marmelos Linn. \\
\hline 28 & Yavai & Hordeum vulgare L. & Kadalai payaru & Cicer arietinum Linn. \\
\hline
\end{tabular}

*The group of 8 raw materials belonging to a common varkam (category): Seeragam (Cuminum cyminum Linn.), Karinjeeragam (Nigella sativa Linn.), Chukku (Zingiber officinale Rosc.), Milagu (Piper nigrum Linn.), Thippili (Piper longum L.), Induppu (Halite) and Perunkayam (Ferrula asafoetida Linn)

\section{Categorization of substitutes}

The substitution defined in the classical Siddha literature are broadly classified as follows:

\section{a. Substitution with different parts of the same herb}

It is a very common exercise of reasonable substitution in which, if the specific part of a plant designated is absent an alternative part added up to meet the requirement of the formulation. The roots of so many herbs are the primary source for most of the herbal formulation in Siddha medicine as in the case of its absence or reduced quantity of supply; the aerial parts or stem is added as in the case of perum panchamoolam (5 primary root parts used in Siddha medicine). ${ }^{10}$ Sometimes samoolam (whole plant part) is used to meet the needed measure. This also includes the type of substitution by bulk addition like the usage of the whole root of kodiveli (Plumbago zeylanica L.) instead of root bark and in $p u n g u$ (Pongamia pinnata (L.) Pierre) instead of its root bark, stem bark is used in the formulations. In most cases, the whole fruit of Elam (Elettaria cardamomum (L.) Maton) is used, even if the formulation insists on the usage of its seed only. (11)

\section{b. Substitution within the same species}

The plants belonging to the same species of Nyctaginacea family-like Charanai (Trianthema portulacastrum Linn.), vellai charanai (White variety of Trianthema decandra Linn.), (small variety Trianthema triquetra Rottler \& Willd.) are used as substitutes for each other based on their common therapeutic effects. Likewise, the substitution of perarathai (Alpinia galanga (L.) Willd.) with chittarathai (Alpinia officinarum Hance) has similar morphology and pharmacology. ( 10$)$ Alpinia calcarata (Haw.) Roscoe commonly substituted for Alpinia officinarum Hance in Tamil Nadu due to its availability.

\section{c. Substitution with different species of the same family}

A s an example, Arathai (Alpinia officinarum Hance) substituted with Chukku (Zingiber officinale Roscoe) which are morphologically dissimilar. The identical source material is used in both, and there is significant similarity in traditional attributes like taste, potency, and division (Table 3). Both share almost the same general property, actions, and medicinal uses. Many scientific studies view its common pharmacological activities also. (35-38)

\begin{tabular}{|l|l|l|}
\hline \multicolumn{2}{|c|}{ Table 3 - Substitution with different species of the same botanical family } \\
\hline Attributes & Original raw drug & Standard substitute \\
\hline Name & Arathai & Chukku \\
\hline Scientific name & Alpinia officinarum Linn. & Zingiber officinale Rosc \\
\hline Family & Zingiberaceae & Zingiberaceae \\
\hline Source (Saram) & Rhizome & Rhizome \\
\hline Suvai (Taste) & Karppu (Pungent) & Karppu (Pungent) \\
\hline Thanmai (Potency) & Veppam (Hot) & Veppam (Hot) \\
\hline Pirivu (Division) & Karppu (Pungent) & Karppu (Pungent) \\
\hline
\end{tabular}


Pothugunam (General property)
Iraippu (Bronchial asthma)

Irumal (Cough)

Iyyam (Phlegmatic disorders)

Karappan (Eczema)

Kayam (Tuberculosis)

Marbunoi (Cardiac diseases)

Moolam (Hemorrhoids)

Sobai (Dropsy)

Vanthi (Emesis)

Sanni (Delirium)

Suram (Fever)

Valikutram (Vatha diseases)

Vayu (Gaseous disturbances)

Akattuvayvaktri (Carminative)

Pasitheethoondi (Stomachic)

Ceykai

(Pharmacological action)

Veppamundakki (Stimulant)

Veppakatri (Febrifuge)

Kozhaiakatri (Expectorant)

Analgesic

Anti-cancer

Antiemetic

Anti-inflammatory

Antilipidemic

Anti-microbial

Anti-oxidant

Antiviral

Hepatoprotective

Platelet Activating Factor (PAF)

inhibitory action

Vasorelaxant

Respiratory ailments like whooping

cough, bronchial catarrh and asthma.

Therapeutic uses
Rheumatism

Throat affections

Fever
Iraippu (Bronchial asthma)

Irumal (Cough)

Iyyasuram (Fever due to phlegmatic origin)

Kathukuthal (Pricking pain inside the ears)

Kazhichal (Diarrhoel diseases)

Mughanoi (Diseases of the face)

Keezhvainoi (Diseases of the anorectal region)

Neeretram (Sinusitis)

Puliyeppam (Sour belching)

Seriyamai (Dyspepsia)

Thalainoi (Diseases of the head)

Vayitrukuthal (Pricking sensation of the abdomen)

Vayu gunmam (Painful Gastrointestinal affections)

Vayitruppisam (Bloating sensation of the abdomen)

Akattuvayvaktri (Carminative)

Pasitheethoondi (Stomachic)

Veppamundakki (Stimulant)

Analgesic

Antitumorogenic

Antiemetic

Anti-inflammatory

Antilipidemic

Antimicrobial

Antioxidant

Antiviral

Hepatoprotective

Antithrombotic

Antiplatelet activity

Antihypertensive

Dyspnoea

Cough

Arthritis

Ear diseases

Dyspepsia

\section{d. Substitution with herbs belonging to the different families: \\ For eg. Cinnamomum verum J.Presl is} substituted for Holarrhena antidysenterica (Roth) Wall. ex A.DC. which belong to an entirely different family. Both share similar traditional attributes. (12)

\section{e. Substitutes to Animal products:}

Indrakopam (Mutilla occidentalis - insect) is used by the traditional Siddha healers for numerous ailments. For substituting the material, Valuzhuvai (Celastrus paniculatus Willd.) is selected which has the following attributes identical to the animal material (Table 4). In this case, there are no relative morphological, organoleptic resemblances of both of the raw drugs belonging to two different sources. The identical potency, general property, special action, and medicinal uses may be the deciding factor for the substitution. It has been advocated to use this alternative in conditions where the original drug does not suit the health condition of the patient due to its potency. The substitution aimed to minimize the predictable ill effects without changing the general therapeutic outcome needed. (38)

White goats milk is mentioned as an important nutritional regimen in Siddha medicine for respiratory ailments. In the time of its unavailability, cow's milk boiled with dry ginger and root of Tragia involucrata $\mathrm{L}$. is considered equivalent to the same regimen is substituted. Palakarai (Cowrie shell Cypraea moneta) can be substituted with muthuchippi (Oyster shell - Pinctada vulgaris) having almost the same property.(12,38) Mothers milk can be substituted with cow's milk. (11).

\begin{tabular}{|l|l|l|}
\hline \multicolumn{1}{|c|}{ Table 4- Substitutes to Animal products } & \\
\hline Attributes & Original raw drug & Standard substitute \\
\hline Name & Indrakopam & Valuzhuvai \\
\hline Scientific name & Mutilla occidentalis & Celastrus paniculatus. Willd \\
\hline Saram (Source) & Insect- Animal origin & Seed- Plant origin \\
\hline Thanmai (Potency) & Veppam (Hot Potency) & Veppam (Hot Potency) \\
\hline Panchabootha-adipadai (Five element class) & Fire & Fire \\
\hline $\begin{array}{l}\text { Pothugunam } \\
\text { (General property) }\end{array}$ & $\begin{array}{l}\text { Sukkila nattam (Spermatorrhoea) } \\
\text { Rejuvenator }\end{array}$ & Cures phlegmatic disorders \\
\hline & Cures phlegmatic disorders & Hemiparesis (Parisa Vayu) \\
\hline
\end{tabular}




\begin{tabular}{|c|c|c|}
\hline $\begin{array}{l}\text { Ceykai } \\
\text { (Special Action) }\end{array}$ & $\begin{array}{l}\text { Nervine tonic } \\
\text { Tonic and spermatogenic } \\
\text { Aphrodisiac } \\
\text { Strengthens muscles }\end{array}$ & $\begin{array}{l}\text { Nervine tonic } \\
\text { Tonic and spermatogenic } \\
\text { Aphrodisiac } \\
\text { Stimulant }\end{array}$ \\
\hline Maruthva gunam (Therapeutic uses) & $\begin{array}{l}\text { Hemiparesis (Parisa Vayu), Nervine } \\
\text { diseases } \\
\text { Neuralgia } \\
\text { Whooping cough }\end{array}$ & $\begin{array}{l}\text { Hemiparesis (Parisa Vayu) } \\
\text { Neuralgia }\end{array}$ \\
\hline
\end{tabular}

\section{f. Mineral and metal substitutes:}

The crude metal gold is included as one of the main components in so many effective formulations in Siddha medicine meant for respiratory ailments and male infertility. (38) By considering the cost factor, it is advised to substitute with metal silver, which is equally effective and economical than the original material (Table 5). (12)

\begin{tabular}{|c|c|c|}
\hline \multicolumn{3}{|c|}{ Table 5- Substitution of Metallic crude drugs } \\
\hline Attributes & Original raw drug & Standard substitute \\
\hline Name & Pon (Gold) & Velli (Silver) \\
\hline Scientific name & Aurum & Argentum \\
\hline Varkam (Category) & Inippu (Sweet) & Inippu (Sweet) \\
\hline Suvai (Taste) & Inippu (Sweet) & Inippu (Sweet) \\
\hline Thanmai (Potency) & Veppam (Hot) & Thatpam (Cold) \\
\hline Pirivu (Division) & Inippu (Sweet) & Inippu (Sweet) \\
\hline $\begin{array}{l}\text { Pothugunam } \\
\text { (General property) }\end{array}$ & $\begin{array}{l}\text { Irumal (Cough) } \\
\text { Kaphanoi (Phlegmatic diseases) } \\
\text { Kayam (Tuberculosis) } \\
\text { Kozhai (Phlegmatic affections) } \\
\text { Suram (Fever) } \\
\text { Thathunattam (Spermatorrhoea) } \\
\text { Thirithodam/Sanni (Delirium) } \\
\text { Vizhinoi (Eye diseases) }\end{array}$ & $\begin{array}{l}\text { Irumal (Cough) } \\
\text { Kaphanoi (Phlegmatic diseases) } \\
\text { Kayam (Tuberculosis) } \\
\text { Kozhai (Phlegmatic affections) } \\
\text { Puranasuram (Chronic fever) } \\
\text { Ozhukku velai (Leucorrhoea) } \\
\text { Thirithodam/Sanni (Delirium) } \\
\text { Vizhinoi (Eye diseases) }\end{array}$ \\
\hline $\begin{array}{l}\text { Ceykai } \\
\text { (Special Action) }\end{array}$ & $\begin{array}{l}\text { Kamamperukki (Aphrodisiac) } \\
\text { Udal thetri (Tonic) } \\
\text { Narambu uramundakki (Nervine tonic) } \\
\text { Ruthuundakki (Emmenegogue) }\end{array}$ & $\begin{array}{l}\text { Kamamperukki (Aphrodisiac) } \\
\text { Udal uramakki (Tonic) } \\
\text { Isivakatri (Antispasmodic) } \\
\text { Malamilakki (Laxative) } \\
\text { Pasitheethoondi (Stomachic) } \\
\text { Thathuveppakatri (Sedative) } \\
\text { Ullazhaltri (Demulcent) } \\
\text { Veppamundakki (Stimulant) }\end{array}$ \\
\hline
\end{tabular}

\section{g. Substitution with Vaippu sarakku (Synthetic materials):}

Preparation of synthetic substances (Vaippu sarakku) from natural elements that match the therapeutic quality of the original drug is well appreciated in the alchemical part of Siddha science. Such materials are widely used in the absence of crude drugs are essential for the preparation of higher-order medicines of Siddha. Most minerals and rare metals have synthetic substitutes. Few synthetic products which are used as herbal raw drug substitutes are also mentioned. Synthetic substitutes like Induppu (Halite), Turisu (Blue vitriol), Lingam (Cinnabar), Navasaram (Sal Ammoniac), Padikaram (Alum), Venkaram (Borax), Nagam (Zinc metal), Karuvangam (Black lead), Karpooram (Camphor), Pachaikarpooram (Borneo camphor), Sambrani (Boswellia serrata) are some of the examples described in the classics of Tamil medicine. (39-41)

\section{Criteria for selection of standard substitutes}

The criteria of selecting a substitute involve the below stringent aspects. These should be well thought before deciding the ideal substitute for the original material in demand. (Table 6)

\section{Vargam (Category)}

There are six categories of raw drugs based on their principal taste. If both raw drug and its substitute fall under the same category, it is a lead for the selection. (12)

\section{Saram (Main source or morphological identity)}

This includes six divisions of an essential part of a plant material used in medicine. If the original material and its substitute fall under a similar division, it is an advantage for substitution. (12)

\section{Traditional attributes}

The typical characters of a raw material stated in the perspective of Siddha traditional concept are detailed in Table 7. $(12,38,41)$ 
Table 6- Standard substitute (Matru Sarakku) - Criteria of Selection

\section{Vargam (Category in terms of taste)}

\section{(Sweet)}

(Bitter)

(Astringent)

(Pungent)

(Sour)

(Salt)
Saram (Main source of material/ morphological identity)

Ilai Saram (Leaf part)

Ver Saram (Root part)

Kai/Kani Saram (Fruit part)

Vithai Saram (Seed part)

Poo Saram (Flower part)

Pattai Saram (Bark part)

Kattai Saram/vairam (Hard wood part)

Pisin saram (Gum and resin part)

\section{Traditional Attributes}

(Taste Attributes)

(Odour)

(Potency)

(Humoral division)

(Elemental division)

(Disease classifieds)

(General property)

(Specific actions)

(Common therapeutic uses)
Traditional attributes

Suvai

Manam

Thanmai

Mukutra Adipadai

Panchabootha Adipadai

Noi Kanam

Pothu gunam

Ceykai

Maruthuva Gunam

Thus, in Siddha medicine substitutes are considered and selected based on their category of predominant taste, the essential part of the plant used with maximum therapeutic value, morphological resemblances, and traditional attributes. Identical traditional attributes are determined as the core principle of Siddha raw drug substitution. Even if the category or morphological factors differ between substitute and original drug, it is obligatory to have substantial equivalency in traditional qualities to validate it as the standard substitute.

\section{Conclusion}

Many of the raw drug substitution practices in the market are hazardous to health and further needs vigorous studies for establishing its genuineness with the original material. A thoughtful scientific approach on the rationality of the Siddha concept of Matru sarakku (Standard drug substitution) could lead to novel means of detecting appropriate raw drug alternatives to solve many of the issues faced by the herbal industries. Traditional attributes of a raw drug are the main deciding factor for affirming it as a standard substitute or not. The substitutes as mentioned in the classical works should be made for systematic evaluation by pharmacognostic and phytochemical studies. This will ensure its justification in the current practices for its effective implementation.

Effective phases initiated in the field of conservation and cultivation of endangered species, stringent policies to tackle adulteration and illogical substitution is the only long-term resolution to ensure the availability of original raw drugs, which is the prime base for AYUSH health care systems.

\section{References}

1. Jiang C, Yuan Y, Yang G, Jin Y, Liu L, Zhao Y, Huang L, Fluorescence visual detection of herbal product substitutions at terminal herbal markets by CCP-based FRET technique. Scientific reports. October, 2016; 6(1);1-9.

2. Divya Kallingilkalathil Gopi, Rubeena Mattummal, Sunil Kumar Koppala Narayana, Sathiyarajeswaran Parameswaran, IUCN Red Listed Medicinal Plants of Siddha. JRes Sid Med. December 2018; 1(1);15-22.

3. Kumar JS, Krishna V, Seethapathy GS, Ganesan R, Ravikanth G, Shaanker RU, Assessment of adulteration in raw herbal trade of important medicinal plants of India using DNA barcoding. 3 Biotech. March 2018; 8(3);1-8.

4. Ved DK, Goraya GS, Demand and supply of medicinal plants. Medplant-ENVIS Newsletter on Medicinal Plants. December 2008;1(1); 2-4.

5. Seethapathy GS, Ganesh D, Kumar JU, Senthilkumar U, Newmaster SG, Ragupathy S, Shaanker RU, Ravikanth G, Assessing product adulteration in natural health products for laxative yielding plants, Cassia, Senna, and Chamaecrista, in Southern India using DNA barcoding. International Journal of Legal Medicine. July 2015;129(4); 693-700.

6. Nagarajan M, Kuruvilla GR, Kumar KS, Venkatasubramanian P, Abhava pratinidhi dravya: A comparative phytochemistry of Ativisha, Musta and related species. Journal of Ayurveda and integrative medicine. January 2015 Jan;6(1); 53.

7. Joshi PR, Patel BR, Shukla VJ, An overview of the causes of current practices in Pratinidhi Dravyas (substitution of drugs) in Ayurveda including newer techniques for their evaluation. Ayu. October 2012; 33(4); 481. 
Shyamala Rajkumar et.al., Concept of standard raw drug substitution in Traditional Siddha Medicine - A Review

8. Youngken, Heber W. Textbook of Pharmacognosy. $6^{\text {th }}$ ed. Philadelphia; Blakiston Co; 1950. 100.

9. N. Kandaswamy Pillai. History of Siddha Medicine. $2^{\text {nd }}$ Edition. Chennai; Department of Indian Medicine and Homoeopathy; 2018.

10. K.S.Murugesa mudhaliyar. Gunapadam-mooligai vaguppu (Materia medica - Part 1). 3rd Edition. Chennai; Department of Indian Medicine and Homoeopathy; 2008.

11. Anonymous. The Siddha Formulary of India. $1^{\text {st }}$ Edition. New Delhi; Department of Ayush; 2011.

12. S. Prema. Agasthiyar Vaidhya Chinthamani - Part 2. $3^{\text {rd }}$ Edition. Chennai; Thamarai Noolagam; 2006.

13. T. V. Sambasivam Pillai: Dictionary of Medicine, Chemistry, Botany and Allied Sciences. $3^{\text {rd }}$ Edition. Chennai; Govt. Central Press; 1995.

14. Dr. D.S. Vaniswari, Dr.K.Shyamala, Dr.K.Sivaranjini, Adulterants and Substitutes for Herbal Plants in Siddha system of medicine. World Journal of Pharmacy and Pharmaceutical Sciences January 2018; 7 (1); 244-268.

15. Santapau H, Henry AN. A dictionary of the flowering plants in India. 2nd ed. New Delhi; Publications \& Information Directorate, Council of Scientific \& Industrial Research; 1994.

16. Oleg Polunin, Adam Stainton. Flowers of the Himalayas. $1^{\text {st }}$ ed. New Delhi; Oxford University Press; 1984.

17. Cecil J. Saldanha. Flora of Karnataka. $1^{\text {st }}$ ed. New Delhi; Oxford \& IBH Publishing Co;1984.

18. R.N. Chopra, S.L. Nayar, I.C. Chopra. Glossary of Indian Medicinal Plants. $1^{\text {st }}$ ed. New Delhi; Council of Scientific Industrial Research; 1956.

19. A. Venkateswarlu, P.V. Bheravamurthy, P. Narasimha Rao. The Flora of Visakhapatnam. ${ }^{\text {st }}$ ed. Hyderabad; Academy of Sciences; 1972.

20. L.H. Bailey, E.Z. Bailey. Hortus Third: A Concise Dictionary of Plants cultivated in the United States and Canada. 1st ed. London; MacMillan Publishers; 1978.

21. J.K. Maheswar. The Flora of Delhi. 1 st ed. New Delhi; Council of Scientific \& Industrial Research; 1963.

22. Anonymous. The Wealth of India - A Dictionary of Indian Raw Materials. 1st ed. New Delhi; Publications \& Information Directorate, CSIR; 1985.

23. U.N. Kanjilal. Flora of Assam. 1st ed. Shilong; Government of Assam; 1934.

24. R.N. Chopra, R.L. Badhwar, S. Ghosh. Poisonous Plants of India. 1 st ed. Shilong; Indian Council of Agricultural Research; 1965.

25. B. Mukerji. Indian Pharmaceutical Codex. $1^{\text {st }}$ ed. New Delhi; Council of Scientific \& Industrial Research;1953.

26. R.N. Chopra, I.C. Chopra, B.S. Verma. Supplement to Glossary of Indian Medicinal Plants. 1 ${ }^{\text {st }}$ ed. New
Delhi; Publications \& Information Directorate; 1969.

27. J.C. Th. Uphof. Dictionary of Economic plants. $1^{\text {st }}$ ed. Cramer; Verlag con J;1968.

28. C.R. Babu. Herbaceous Flora of Dehra Dun. 1st ed. New Delhi; Publications \& Information Directorate, CSIR; 1977.

29. C.H. Drury. The Useful Plants of India with notices of their Chief value in Commerce, Medicine and the Arts. 1st ed. New Delhi; Periodical Experts Book Agency; 1978.

30. J.F. Dastur. Useful Plants of India and Pakistan: A Popular Handbook of Trees and plants of Industrial Economics and commercial Utility. 1 ${ }^{\text {st }}$ ed. Bombay; D.B. Taraporevala Sons \& Co., Ltd; 1956.

31. T.E. Wallis. Textbook of Pharmacognosy. $1^{\text {st }}$ ed. London; J.\& A. Churchill Ltd;1960.

32. Rao CK, Geetha BL, Suresh GE. Red list of threatened vascular plant species in India. $1^{\text {st }}$ ed. Kolkata; Botanical Survey of India; 2003.

33. Kahdoliya DH, Makwana S, Nakum SB, Pandya P, Patel B, A comparative pharmacognostical and prilimary phytochemical evaluation of Bharangi (Clerodendrumserratum (Linn) Kutz. and Tarkari (Clerodendrum phlomidis (Linn.) f.-root. International Journal of Botany Studies. March 2021; 6 (2); 2021; 29-34

34. Kuppusami mudhaliyaar, Uthamarayan. Siddha vaidhya Thirattu. 6th ed. Chennai; Directorate of Indian Medicine and Homoeopathy; 2006.

35. Kumar G, Loganathan K, Rao B, A Review on Pharmacological and Phytochemical Properties of Zingiber officinale Roscoe (Zingiberaceae). Journal of Pharmacy Research. January 2011; 1(4); 2963-6.

36. Abubakar IB, Malami I, Yahaya Y, Sule SM, A review on the ethnomedicinal uses, phytochemistry and pharmacology of Alpinia officinarum Hance. Journal of ethnopharmacology. October 2018; 5; $224 ; 45-62$.

37. Nadkarni, K.M. Dr. K. M. Nadkarni's Indian Materia medica: with Ayurvedic, Unani-Tibbi, Siddha, allopathic, homeopathic, naturopathic \& home remedies, appendices \& indexes. $2^{\text {nd }}$ ed. Mumbai; Popular Prakashan; 1996.

38. R. Thyagarajan. Gunapadam (Thathu Jeeva Vaguppu) - Part $2 \& 3.8^{\text {th }}$ ed. Mumbai; Department of Indian Medicine and Homoeopathy; 2013.

39. Ponnambalampillai, Veerasaminayadu. Bohamunivar Sarakku Vaippu 800. 1 ${ }^{\text {st }}$ ed. Chennai; Sabhapathi pillai; 1893.

40. Ramaguru samikonar, Shanmugha Mudaliyar. Machamuni Nayanar Vaippu. $1^{\text {st }}$ ed. Chennai; Duraisami; 1927.

41. Mohammed abdulla sahib. Agathiyar Vaidhya Sathagam. 1st ed. Chennai; Pazhani Thandayuthapaani swami Thirukkoil Siddha Maruthuva nool Veliyeettu Kuzhu;1975. 